RASĀYAN J. Chem.

Vol. 13 | No. 1 |327 - 332| January - March | 2020 ISSN: 0974-1496 | e-ISSN: 0976-0083 | CODEN: RJCABP

RJC http://www.rasayanjournal.com http://www.rasayanjournal.co.in

\title{
BIOACTIVE COMPOUND FROM THE MANGROVE PLANT ENDOPHYTIC FUNGUS Diaporthe amygdali SgKB4
}

\author{
D. Handayani ${ }^{1, *}$, T. Wahyuningsih ${ }^{1}$, Rustini ${ }^{1}$, M.A. Artasasta ${ }^{1,2}$, \\ A. E. Putra ${ }^{2}$ and P. Proksch ${ }^{3}$ \\ ${ }^{1}$ Laboratory of Sumatran Biota/Faculty of Pharmacy, Andalas University, \\ Padang 25163, Indonesia \\ ${ }^{2}$ Depertment of Biomedical, Faculty of Medicine, Andalas University, Padang 25163, Indonesia \\ ${ }^{3}$ Institut für Pharmazeutische Biologie und Biotechnologie, Heinrich-Heine-Universität \\ Düsseldorf, Universitätsstrasse 1, 40225 Düsseldorf, Germany \\ *E-mail: dianhandayani@phar.unand.ac.id
}

\begin{abstract}
Investigation of the chemical constituent and antibacterial activity of Diaporthe amygdali SgKB4, an endophytic fungal strain isolated from the West Sumatran mangrove plant Sonneratiagriffithii Kurz led to the isolation of compound 1. The isolation of compound 1 was achieved by column chromatography with step gradient polarity (SGP) method and purification by recrystallization. The structure of compound $\mathbf{1}$ was elucidated based on nuclear magnetic resonance (NMR) spectroscopy data. Based on IR, 1D, and 2D-NMR, as well as MS data, the isolated compound is cytochalasin H. This compound showed mild antibacterial activity against some pathogenic bacteria. This is the first report on the isolation of cytochalasin $\mathrm{H}$ from the endophytic fungus D.amygdali.

Keywords: Diaporthe amygdali, Endophytic fungus, Sonneratia griffithii, Cytochalasin H, Antibacterial Activity, MRSA

(C) RASĀYAN. All rights reserved

\section{INTRODUCTION}

Endophytic fungi are a kind of plant-associated microbes living in a colony. This association occurs without any immediate in internal tissues of their host plants. ${ }^{1,2}$ They have been shown to fight pathogens by producing secondary metabolites and these compounds can solve the problem of increasing resistance of human or plant pathogenic bacteria. ${ }^{3,4}$ Mangrove endophytic fungi, as microorganisms living in highly specific habitats, have proven to be rich sources of secondary metabolites with great potential for development as drugs and research tools. ${ }^{5}$ In this study, we investigated the fungal endophytic Diaporthe amygdali SgkB4 isolated from bark tissues of the mangrove plant $S$. griffithii Kurz growing in the Bungus coast of Padang, West Sumatera, Indonesia. ${ }^{6}$
\end{abstract}

\section{General Experimental Procedures}

\section{EXPERIMENTAL}

A Perkin-Elmer Spectrum One FT-IR Instrument was used for IR spectrum experiments. 1D and 2D NMR spectra were recorded on Bruker ARX 500, ARX 400 or AVANCE DMX 600 NMR spectrometers. The chromatographic silica gel 60 was provided by Merck $^{\circledR}$. TLC analysis was performed on silica gel 60 $\mathrm{F}_{254 \mathrm{~nm}}\left(\mathrm{Merck}^{\circledR}\right)$. Solvents were distilled prior to use, and spectral grade solvents were used for spectroscopic measurements.

\section{Fungal Strain}

The endophytic fungus D. amygdali SgkB4 was isolated from the bark of S. griffithii Kurz growing at Bungus coast, West Sumatera, Indonesia by the previous researchers. ${ }^{6,7}$ The fungus was stored at the Laboratory of Sumatran Biota, Faculty of Pharmacy, Andalas University, Padang, Indonesia.

Rasayan J. Chem., 13(1), 327-332(2020)

http://dx.doi.org/10.31788/RJC.2020.1315589

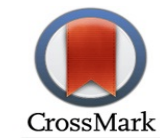


RASĀYAN J. Chem.

Vol. 13 | No. 1 |327 - 332| January - March | 2020

\section{Molecular Identification of Mangrove-Associated Fungi}

The characterization of endophytic fungi was performed in macroscopic examination included surface, colors, and the edge of each colony. The molecular identification was performed out using an internal transcribed spacer (ITS) DNA barcode with special primer pairs for fungi, by following the procedures carried out by Saitoh, et.al. ${ }^{8}$ PCR product was sequenced by First Base, Malaysia. BLAST program on NCBI was used for analyzing the sequence. MEGA 7.0 software was used for constructing the phylogenetic tree. ${ }^{9}$

\section{Cultivation}

The fungus was grown in liquid Sabouraud Dextrose Broth (SDB) medium (6 L) and incubated at room temperature $\left(25^{\circ} \mathrm{C}\right)$ for 4 weeks. The liquid medium was extracted with ethyl acetate (EtOAc) after having been separated from the mycelia by filtration.

\section{Isolation of Secondary Metabolites}

EtOAc extract was purified by silica gel column chromatography and was eluted with a mixture of nhexane, EtOAc, and $\mathrm{MeOH}$ respectively which yielded eight fractions (F1, F2, F3, F4, F5, F6, F7, and F8). Among these, F4 and F5 exhibited antibacterial activity against several pathogenic bacteria. F4 was subjected to further silica gel chromatography and eluted with a mixture of n-hexane and EtOAc to give four fractions (F4-1, F4-2, F4-3, and F4-4). F4-1 was recrystallized with n-hexane and EtOAc, resulting in the isolation of compound $\mathbf{1}(25 \mathrm{mg})$.

\section{Compound 1 (Cytochalasin $\mathbf{H})$}

Colorless needle crystal, ${ }^{1} \mathrm{H} \quad \mathrm{NMR} \quad(600 \quad \mathrm{MHz}, \quad$ DMSO-d6) $\quad \delta \quad 8.04-8.00 \quad(\mathrm{~m}, \quad 1 \mathrm{H})$, $7.30(\mathrm{t}, J=7.5 \mathrm{~Hz}, 2 \mathrm{H}), 7.25-7.19(\mathrm{~m}, 1 \mathrm{H}), 7.18-7.13(\mathrm{~m}, 2 \mathrm{H}), 5.68(\mathrm{dd}, J=16.7,2.3 \mathrm{~Hz}, 1 \mathrm{H}), 5.54$ (ddd, $J=15.4,9.5,1.4 \mathrm{~Hz}, 1 \mathrm{H}), 5.38(\mathrm{dd}, J=16.7,2.4 \mathrm{~Hz}, 1 \mathrm{H}), 5.30(\mathrm{t}, J=2.4 \mathrm{~Hz}, 1 \mathrm{H}), 5.08$ (ddd, $J=15.6,10.8$, $4.8 \mathrm{~Hz}, 1 \mathrm{H}), 5.04(\mathrm{~d}, J=1.6 \mathrm{~Hz}, 1 \mathrm{H}), 4.80(\mathrm{q}, J=1.6 \mathrm{~Hz}, 1 \mathrm{H}), 4.50(\mathrm{~d}, J=6.1 \mathrm{~Hz}, 1 \mathrm{H}), 4.38(\mathrm{~s}, 1 \mathrm{H}), 3.63-3.59$ (m, 1H), 3.12-3.08 (m, 1H), $2.82(\mathrm{dd}, J=13.1,5.0 \mathrm{~Hz}, 1 \mathrm{H}), 2.75$ (t, $J=9.9 \mathrm{~Hz}, 1 \mathrm{H}), 2.56$ (dd, $J=13.1,8.6$ $\mathrm{Hz}, 2 \mathrm{H}), 2.24(\mathrm{~s}, 3 \mathrm{H})$.

\section{Antibacterial Activity Testing}

Compound 1 was tested against human pathogenic bacteria; Gram-positive: Staphylococcus aureus ATCC 25923, Staphylococcus epidermidis ATCC 12228, Bacillus subtilis ATCC 6633; Gram-negative: Escherichia coli ATCC 25922, Vibrio cholerae Inaba, Salmonella typosa NCTCC 786; and MethicillinResistant Staphylococcus aureus (MRSA) with agar disc diffusion method and with chloramphenicol as a positive control. ${ }^{10}$ Compound 1 was prepared in DMSO at a concentration of $50 \mathrm{mg} / \mathrm{ml}$. Antibacterial activity was detected after incubation for $24 \mathrm{~h}$ at $30^{\circ} \mathrm{C}$. A clear zone of inhibition in the media was considered as an indicator of antibacterial activity. ${ }^{11,12,13}$

\section{Identification of Fungal Strain}

\section{RESULTS AND DISCUSSION}

PCR product was successfully obtained a DNA band of 1656 bp (Fig.-1). Based on molecular identification result with $18 \mathrm{~S}$ rRNA primer, the endophytic fungus was identified as Diaporthe amygdali with $99 \%$ similarity compared to a DNA sequence at GenBank NCBI. Microorganisms with differences less than $2 \%$ or similarity more than $97 \%$ of 18 S rRNA, could be concluded as identical species. ${ }^{14}$

There were five clades consist of the phylogenetic tree. Coniochaeta was in clade 1, group of Lecythopora was in clade 2, Aspergillus was in clade 3, Diaporthe was in clade 4 and Cladosporium was in clade 5. Phylogenetic tree analysis confirmed that sgkb4 isolate had similarities with Diaporthe amygdali (Fig.-2).

\section{Characterization of Pure Compound}

Compound 1 was obtained as a colorless needle crystal. The IR spectrum showed absorption bands for amine or hydroxyl group $\left(3276 \mathrm{~cm}^{-1}\right)$ and carbonyl group $\left(1677 \mathrm{~cm}^{-1}\right)$. The ESIMS spectrum showed $\mathrm{m} / \mathrm{z}$ 
RASĀYAN J. Chem.

Vol. 13 | No. 1 |327 - 332| January - March | 2020

data of 493, 476, 434, 416, 398, 392, 251, 172. The IR spectrum and MS data of compound 1 were confirmed by its ${ }^{1} \mathrm{H}$ and ${ }^{13} \mathrm{C}$ NMR data and 2D NMR (COSY, HMQC and HMBC spectra). The NMR spectra were compared to the literature and it was concluded that compound $\mathbf{1}$ is identical to cytochalasin H (Fig. -3 and Table-1). ${ }^{15}$

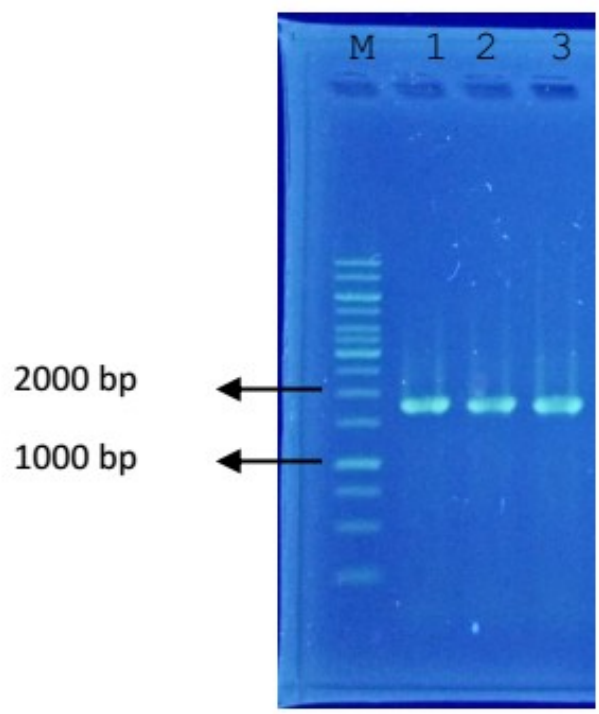

Fig.-1: The PCR product of the 18S rRNA Gene From SgKB4 isolated from S.griffithii Kurz.

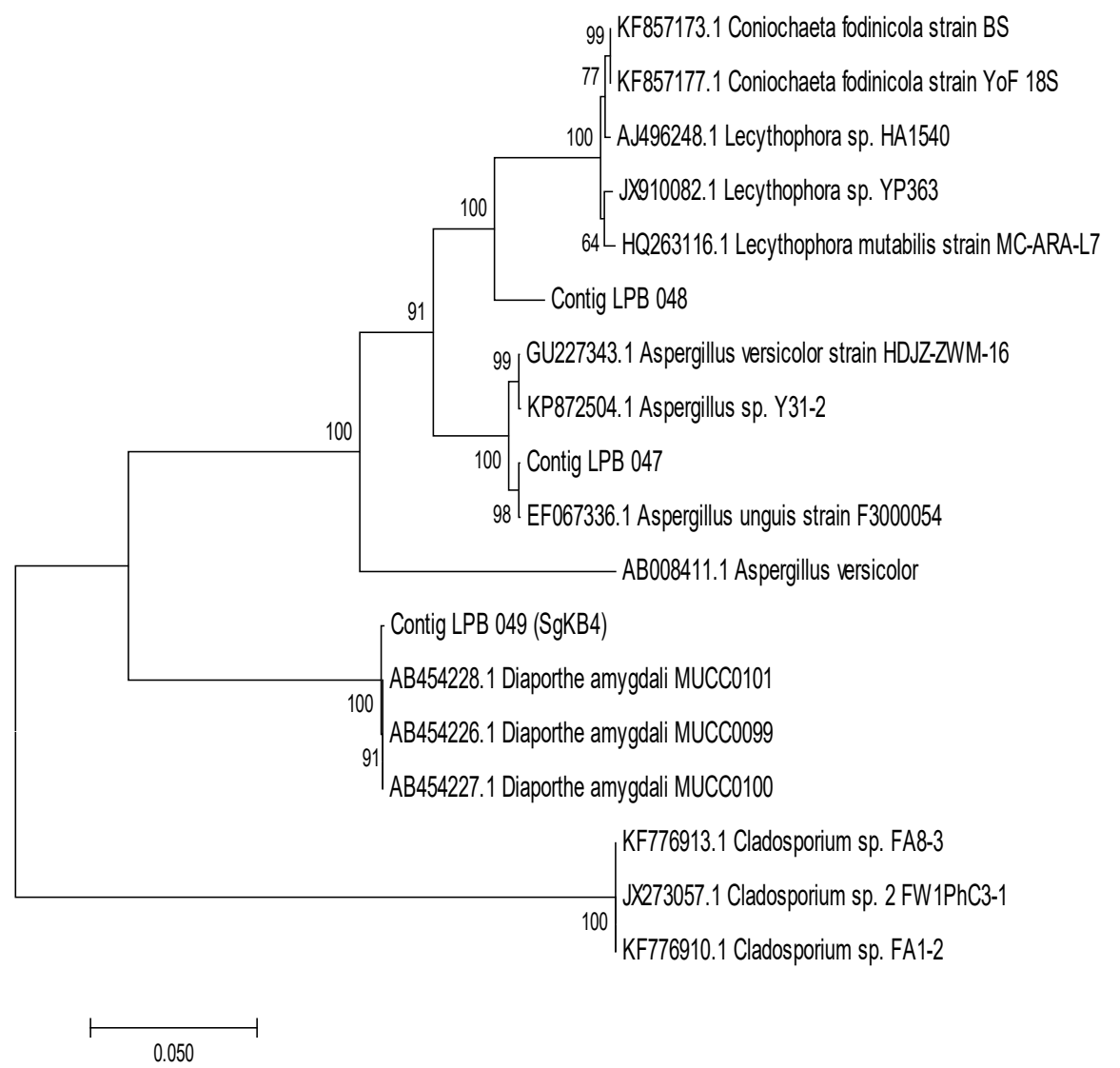

Fig.-2: The Phylogenetic Tree using the Neighbor-joining Method from Some of the Fungi isolates derived S.griffithii Kurz and Some Strain of Coniochaeta, Lecythopora, Aspergillus, Diaporthe, and Cladosporium. The Scale bar indicates a 0.05 substitution Nucleotide Position 
RASĀYAN J. Chem.

Vol. 13 | No. 1 |327 - 332| January - March | 2020

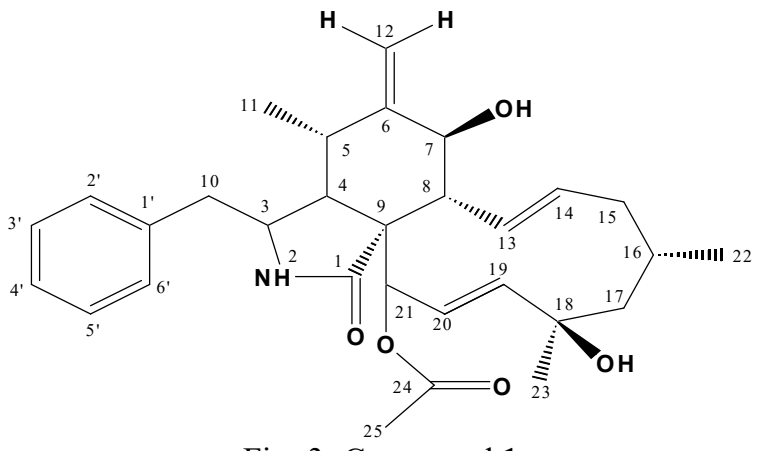

Fig.-3: Compound 1

Table-1: ${ }^{1} \mathrm{H}$ and ${ }^{13} \mathrm{C}$ NMR Data of isolated Compound 1 in DMSO- $d 6$

\begin{tabular}{|c|c|c|}
\hline No. & ${ }^{13} \mathrm{C}(\delta$ in $\mathrm{ppm})$ & ${ }^{1} \mathrm{H}(\delta$ in $\mathrm{ppm}, J$ in $\mathrm{Hz})$ \\
\hline 1 & 174.0 & - \\
\hline 2 & $\mathrm{NH}$ & $8.01(\mathrm{~m}, 1 \mathrm{H})$ \\
\hline 3 & 52.0 & $3.09(\mathrm{~m}, 1 \mathrm{H})$ \\
\hline 4 & 48.0 & $1.98(\mathrm{dd}, 2.8,5.5,1 \mathrm{H})$ \\
\hline 5 & 32.0 & $2.55(\mathrm{dd}, 8.6,13.1,1 \mathrm{H})$ \\
\hline 6 & 151.0 & - \\
\hline 7 & 70.5 & $3.61(\mathrm{~m}, 1 \mathrm{H})$ \\
\hline 8 & 46.5 & $2.75(\mathrm{t}, 9.9,1 \mathrm{H})$ \\
\hline 9 & 54.0 & - \\
\hline 10 & 44.0 & $\begin{array}{l}2.56(\mathrm{dd}, 8.6,13.1,1 \mathrm{H}) \\
2.82(\mathrm{dd}, 5.0,13.1,1 \mathrm{H})\end{array}$ \\
\hline 11 & 13.0 & $0.37(\mathrm{~d}, 3 \mathrm{H})$ \\
\hline 12 & 111.5 & $\begin{array}{l}4.80(\mathrm{q}, 1.6,1 \mathrm{H}) \\
5.04(\mathrm{~d}, 1.6,1 \mathrm{H})\end{array}$ \\
\hline 13 & 128.0 & $5.53(\mathrm{ddd}, 1.4,9.5,15.4,1 \mathrm{H})$ \\
\hline 14 & 134.5 & $5.08(\mathrm{ddd}, 4.8,10.8,15.6,1 \mathrm{H})$ \\
\hline 15 & 43.0 & $\begin{array}{c}1.61(\mathrm{~m}, 1 \mathrm{H}) \\
1.89(\mathrm{dd}, 4.6,12.4,1 \mathrm{H})\end{array}$ \\
\hline 16 & 28.0 & $1.68(\mathrm{~m}, 1 \mathrm{H})$ \\
\hline 17 & 53.0 & $\begin{array}{l}1.40(\mathrm{dd}, 1 \mathrm{H}) \\
1.61(\mathrm{~m}, 1 \mathrm{H})\end{array}$ \\
\hline 18 & 72.5 & - \\
\hline 19 & 125.0 & $5.38(\mathrm{dd}, 2.4,16.7,1 \mathrm{H})$ \\
\hline 20 & 138.0 & $5.67(\mathrm{dd}, 2.3,16.7,1 \mathrm{H})$ \\
\hline 21 & 77.0 & $5.30(\mathrm{t}, 2.4,1 \mathrm{H})$ \\
\hline 22 & 26.0 & $0.95(\mathrm{~d}, 3 \mathrm{H})$ \\
\hline 23 & 31.0 & $1.14(\mathrm{~s}, 3 \mathrm{H})$ \\
\hline 24 & 170.0 & - \\
\hline 25 & 21.0 & $2.24(\mathrm{~s}, 3 \mathrm{H})$ \\
\hline $1^{\prime}$ & 137.5 & - \\
\hline $\begin{array}{l}2^{\prime} / 6 \\
3^{\prime} / 5 \\
\end{array}$ & 129.0 & $\begin{array}{c}7.15(\mathrm{~m}, 2 \mathrm{H}) \\
7.30(\mathrm{t}, 7.5,2 \mathrm{H})\end{array}$ \\
\hline 4 ' & 126.5 & $7.22(\mathrm{~m}, 1 \mathrm{H})$ \\
\hline 7-OH & - & $4.49(\mathrm{~d}, 6.1,1 \mathrm{H})$ \\
\hline $18-\mathrm{OH}$ & - & $4.38(\mathrm{~s}, 1 \mathrm{H})$ \\
\hline
\end{tabular}

Cytochalasin A and B were first isolated in 1966 as a metabolite of the Helmiwthosporium dematioideum fungus, while cytochalasin $\mathrm{C}$ and $\mathrm{D}$ were isolated from the fungus Metarrhizium anisopliae. ${ }^{16}$ Cytochalasin $\mathrm{H}$ was first isolated in 1977 from the fungus Phomopsis paspali. ${ }^{17}$ This compound has also been isolated from Phomopsis sp IFB-E060, an endophytic fungus on the bark of Vaticamangachapoi ${ }^{18}$, from Phomopsis sp By254, an endophytic fungus derived from Gossypium hirsutum root ${ }^{19}$, and from 
RASĀYAN J. Chem.

Vol. 13 | No. 1 |327 - 332| January - March | 2020

Phomopsis sp ZZF08, the endophytic fungus from the mangrove bark, which was collected in Zhanjiang, South China Sea. ${ }^{11}$ This is the first report on the isolation of cytochalasin $\mathrm{H}$ from the endophytic fungus $D$. amygdali. To date, more than 300 cytochalasin analog compounds have been isolated from various species of fungi. Cytochalasinsare widely used for research related to actin in the platelet biology process. They can inhibit actin polymerization by binding to the barbed end of actin filaments and serve as capping compounds, blocking the further addition of monomers. ${ }^{20}$

Cytochalasin $\mathrm{H}$ is part of secondary fungal metabolites that have a complex structure. Bioactivity study of this compound showed a potential lead compound against several cancer cells including inhibiting ROS, a common protein marker of cancer. This compound also exhibited potential antifungal activity against $C$. cladosporioides and C. sphaerosphermum. ${ }^{21}$ Therefore, this compound is important to be developed and $D$. amygdale is one of the fungal that can produce this compound.

A genus of Deaporthe repeatedly showed a rich source of diverse and bioactive metabolites. Chepkirui and Stadler (2017), reported more than 100 polyketide compounds already isolated from genus Deaporthe. Most of them had strong activity against pathogen bacteria (S. pneumonia and S. aureus) such us dihydroanthracenone, diaporthermins $\mathrm{A}$ and $\mathrm{B}$, flavomannin-6,6'-dimethylether and diaporine. ${ }^{22}$ Terpenoid is also produced by Diaporthe, more than 50 terpenoid compounds already isolated. ${ }^{23,24,25,26,27}$ Peptide compounds that already isolated from this genus and gives a lot of interest pharmaceutical. ${ }^{22}$ In our present study, the antibacterial assay of cytochalas in $\mathrm{H}$ was determined. This compound showed mild inhibitory activity against the growth of pathogenic bacteria $S$. aureus ATCC 25923 , S. epidermidis ATCC 12228, B. subtilis ATCC 6633, E. coli ATCC 25922, V. cholerae Inaba, S.typosa NCTCC 786, as well as against MRSA at the concentration of $500 \mu \mathrm{g} / \mathrm{disc}$, respectively (Table 2). Based on this result, cytochalasin $\mathrm{H}$ showed the same degrees of antibacterial activities against the tested bacterial pathogens (Table-1). Some cytochalasin compounds (18-metoxycytochalasin J, cytochalasins H and J) have been reported to possess significant activity against a wide range of microorganisms and cytotoxic properties against human cancer cells with low toxicity to normal non-cancer cells, but no study has been reported on the activity of the cytochalasins H against Methicillin-Resistant Staphylococcus aureus (MRSA). ${ }^{28}$

Table-2: Antibacterial Activities of Compound 1 from D. amygdali

\begin{tabular}{c|c}
\hline \multirow{2}{*}{ Human Pathogenic Bacteria } & Inhibition Zones $(\mathrm{mm}) \pm$ Deviation Standard (SD) \\
\cline { 2 - 2 } & Compound $1(0.5 \mathrm{mg} / \mathrm{disc})$ \\
\hline S.aureus & $9.45 \pm 0.07$ \\
\hline B.subtilis & $9.28 \pm 0.04$ \\
\hline E.coli & $9.65 \pm 0.07$ \\
\hline V.cholerae & $9.03 \pm 0.04$ \\
\hline S.epidermidis & $9.38 \pm 0.04$ \\
\hline S.typhosa & $9.48 \pm 0.04$ \\
\hline MRSA & $9.45 \pm 0.07$ \\
\hline
\end{tabular}

\section{CONCLUSION}

Cytochalasin $\mathrm{H}$ was isolated from the EtOAc extract of the endophytic fungus D. amygdali SgKB4. Based on the results of this study indicate that this compound could be a clinically useful alternative for the treatment some infectious diseases those caused by $S$. aureus ATCC 25923, S. epidermidis ATCC 12228, B. subtilis ATCC 6633, E. coli ATCC 25922, V. cholerae Inaba, S. typosa NCTCC 786, and MRSA, respectively.

\section{ACKNOWLEDGMENT}

The authors gratefully acknowledge the financial support provided by BOPTN of Andalas University, Padang, Indonesia, in the project of "Penenelitian Dasar Unggulan Klaster Riset-Publikasi Guru Besar Universitas Andalas (PDU-KRP1GB-Unand)", No. T/32/UN.1617/PP.OK-KRP1GB/LPPM/2019.

\section{REFERENCES}

1. O. Petrini, P.J. Fisher. Transactions of the British Mycological Society, 91(2),233(1988), DOI: 10.1016/S0007-1536(88)80210-9.

2. K. Clay K. Ecological Society of America, 69(1), 10(1988), DOI: 10.2307/1943155 
RASĀYAN J. Chem.

Vol. 13 | No. 1 |327 - 332| January - March | 2020

3. G.A. Strobel. Critical Reviews in Biotechnology, 22(4), 315(2002), DOI: 10.1080/07388550290789531.

4. H. Yu, L. Zhang, L. Li, C. Zheng, L. Guo, W. Li, P. Sun, and L. Qin. Microbiological Research, 165(6), 437(2010), DOI: 10.1016/j.micres.2009.11.009.

5. M.G. Haygood, E.W. Schmidt, S.K. Davidson, D.J. Faulkner. Journal of Molecular Microbiology and Biotechnology, 1(1), 33(1999), DOI: backlist/jmmb/v/v1/v1n1/06.

6. D. Handayani, H. Rivai, M. Hutabarat, R. Rasyid. Journal of Applied Pharmaceutical Science, 7(04), 209(2017), DOI: 10.7324/JAPS.2017.70431

7. R. Riga, H. Nizar, H. H. Euis. Journal of Applied Pharmaceutical Science, 9(01), 108(2019), DOI: 10.7324/JAPS.2019.90116

8. K.I. Saitoh, K. Togashi, T. Arie, T. Teaoka. Journal of General Plant Pathology, 72(6), 348(2006), DOI: $10.1007 / \mathrm{s} 10327-006-0300-1$

9. S. Kumar, G. Stecher, K. Tamura. Molecular Biology and Evolution, 33(7), 1870(2016), DOI: doi.org/10.1093/molbev/msw054.

10. A.W. Bauer, D.M. Perry, W.M.M. Kirby. A.M.A. Archives of Internal Medicine, 104(2), 208(1959), DOI: $10.1001 /$ archinte.1959.00270080034004

11. M.A. Artasasta, Yanwirasti, M. Taher, A. Djamaan, D. Handayani. Rasayan Journal Chemistry, 12(3), 1463(2019), DOI:10.31788/RJC.2019.1235284

12. Tia O, A. Santoni, A. Dharma, M. Efdi. Rasayan Journal Chemistry, 12(1), 146(2019), DOI: 10.31788/RJC.2019.1215019.

13. A.S. Thangiah. Rasayan Journal Chemistry, 12(1), 300(2019), DOI:10.31788/RJC.2019.1215042

14. K. Meusemann, B.M. von Reumont, S. Simon, F. Roeding, S. Strauss, P. Kuck, I. Ebersberger, M. Walzl, G. Pass, S. Breuer, V. Achter, A. von Haeseler, T. Burmester, H. Hadrys, J.W. Wagele, B. Misof. Molecular Biology and Evolution, 27(11), 2451(2010), DOI:10.1093/molbev/msq130

15. D.C. Aldridge, J.J. Armstrong, R.N. Speake, and W.B. Turner. Chemical Communications, 1, 26(1967), DOI: $10.1039 / \mathrm{C} 19670000026$

16. G.S. Pendse. 1974. Experientia, 30(1), 107(1974), DOI:10.1007/BF01921629

17. S. Li, L. Qian, S.Z. Ping, L.L. Yu, Z.X. Jun, W.Z. Qi, F. Yi, S.Y. Chun, T.R. Xiang. Chinese Journal of Natural Medicine, 12(7), 512(2014), DOI: 10.1016/S1875-5364(14)60080-7

18. J. Fu, Y. Zhou, H.F. Li, Y.H. Ye, and J.H. Guo. African Journal of Microbiology Research,5(10), 1231(2011), DOI: 228474605

19. Y. Tao, X. Zeng, C. Mou, J. Li, X. Cai, Z. She, S. Zhou, Y. Lin. Magnetic Resonance in Chemistry, 46(5), 501(2008), DOI: $10.1002 / \mathrm{mrc} .2194$

20. J.F. Casella, M.D. Flanagan, S. Lin. Nature, 293, 302(1981), DOI: 10.1038/293302a0/293302a0

21. V.M. Chapla, M.L. Zeraik, V.F. Ximenes, L.M. Zanardi, M.N. Lopes, A.J. Cavalheiro, D.H.S Silva, M.C.M. Young, L.M. da Fonseca, V.S. Bolzani, and A.R. Araujo. Molecules, 19,6597(2014), DOI: $10.3390 /$ molecules 19056597

22. C. Chepkirui, M. Stadler. Mycological Progress, 16, 477(2017), DOI: 10.1007/s11557-017-1288-y

23. A.R.B. Ola, A. Debbab, T. Kurtan, H. Brotz-Oesterhelt, H. Arnal. Tetrahedron Letter, 55, 3147(2014), DOI: $10.1016 / j$.tetlet.2014.03.110

24. B. Anupam, A. Shamina, B. Nikoleta, and P. Marjorie. Front Bioscience, 16, 980(2011), DOI: OMC3057757/pdf/nihms223146

25. L. Zhang, W. Wie, T. Wang, Y. Gua, R. Tan, and H.M. Ge. Natural Product Bioprospective, 2, 117(2012a), DOI:10.1007/s13659-012-0023-2

26. F. Zhang, W. Wie, Y. Guo, T. Wang, R.U. Jiao, S. Wenig, R.X. Tan, and H.M. Ge. Journal of Natural Product, 75, 1744(2012b), DOI: 10.1021/np3004112

27. S. Dettrakul, P. Kittakoop, M. Isaka, S. Nopichai, C. Suyarnsestakom, Tanticharoen, M.Y. Thebtaranonthaa. Bioorganic \& Medicinal Chemistry Letters, 13, 1253(2003), DOI:10.1016/S0960894X(03)00111-2

28. J.B. Jouda, J.D. Tamokou, C.D. Mbazoa, C.D. Meli, P. Sarkar, P.K. Bag, and J. Wandji. BMC Complementary and Alternative Medicine, 16, 462(2016), DOI:10.1186/s12906-016-1454-9

[RJC-5589/2019] 